\title{
Modeling the Optimal Portfolio: the Case of the Largest European Stock Exchanges
}

\author{
Florin Aliu \\ Assistant Professor, Faculty of Economics, University for Business \\ and Technology (UBT), Prishtina, Kosovo, e-mail: florin.aliu@ubt-uni.net
}

\author{
Artor Nuhiu \\ Assistant Professor, Faculty of Law, University of Prishtina, Prishtina, Kosovo \\ e-mail: artor.nuhiu@uni-pr.edu (corresponding author)
}

\author{
Besnik Krasniqi \\ Professor, Faculty of Economics, University of Prishtina, Prishtina, Kosovo \\ e-mail: besnik.krasniqi@uni-pr.edu
}

Fisnik Aliu

Faculty of Computer Science and Engineering, University for Business

and Technology (UBT), Prishtina, Kosovo, e-mail: fisnik.aliu@gmail.com

\section{Abstract}

Portfolio optimization is the main concern for portfolio managers. Financial securities are placed within the portfolio based on the investor's risk tolerance. The study measures the risk-reward relationship when the number of stocks in the portfolio increases. Six diverse portfolios have been created with a different number of stocks, such as portfolios with 47 stocks, 95 stocks, 142 stocks, 190 stocks, 239 stocks, and 287 stocks. Stock prices and trading volume were collected on a weekly basis from the six largest European stock exchanges (FTSE100, CAC40, FTSE MIB, IBEX35, DAX, and MDAX). Markowitz's (1952) diversification formula has been used to measure the risk level of the individual portfolios. The results of the study show that the diversification risk constantly decreases when we move from the portfolios with 47 stocks to the portfolios with 287 stocks. The weighted average returns increase on the portfolios with a higher number of stocks, which is contrary to the standard portfolio theories. The results of the study indicate managerial implications for financial investors that are focused exclusively on the largest European stock exchanges.

Keywords: Portfolio diversification, stock exchanges, correlation coefficient, volatility

JEL: G11 


\section{Introduction}

The risk-reward relationship of financial assets is considered an everyday task for portfolio managers. Diversification is used to reduce specific risks imposed on financial assets and expand portfolio benefits. Regardless of the significant number of studies conducted in this area, there are still no widely accepted metrics for measuring portfolio risk (Meucci 2009, pp. 74-79). The concentration level within the portfolio of assets can be measured via the Herfindahl-Hirschman index (Kacperczyk et al. 2005; Kumar 2007) and a portfolio that is concentrated in a few numbers of assets is considered poorly diversified. The major limitation of the weight-based method for measuring risk is that it treats diversification outcomes merely on asset concentration. The correlation within assets in the portfolio is an extra risk component, and a higher correlation within assets increases portfolio risk and vice-versa. The risk-based method indicates that portfolios with less positively correlated assets are well diversified. However, the correlation coefficient might generate misleading results since the portfolio is influenced by multiple factors (Roll 2013, pp. 11-18). The correlation coefficient indicates short-run dependency within assets, while co-integration captures long-term associations. Skintzi and Refenes (2005, pp. 171-197) claim that the average correlation within financial assets is the best measure of diversification risk.

However, Christoffersen et al. (2012, pp. 3711-3751) propose conditional diversification benefits for measuring diversification risk. Volatility measured through the standard deviation of returns influences investor decisions. Higher volatility imposed on the financial securities increases the risk exposure of the portfolio. The portfolio is a complex arrangement of visible and invisible risk components that is barely controlled via ordinary models.

Building a portfolio that would generate the highest diversification benefits is a hot topic among scholars. Markowitz (1952, pp. 77-91) set up the foundations on the diversification risk, called modern portfolio theory (MPT). The theory is based on the allocation of the portfolio assets grounded on the risk tolerance of financial investors. The MPT is constructed under the market efficiency hypothesis, where stock prices signify the ultimate situation of the company. In contrast, stock markets are characterized by various efficiency levels and distorted speculative prices. The theory is generally recognized as the Capital Asset Pricing Model (CAPM), developed by Sharpe (1964, pp. 425-442) and Lintner (1965, pp. 587-615). CAPM indicates the equilibrium risk-return relationship of the financial securities based on two main properties. The first assumption considers that investors hold in their portfolio all possible risky financial assets. The second assumption claims that assets are spread on the equal weights within the portfolio. The model is generally constructed under the efficient market hypothesis (EMH). Fama (1968, pp. 29-40) considers that stock prices tend toward equilibrium (intrinsic value) when stock markets are efficient. The EMH was extensively criticized after the financial crisis of 2008 when stock prices remained beyond their intrinsic value for a long period. CAPM is largely used as a discount rate 
indicator to determine the equity value of a company (Damodaran 2012, p. 324). Besides portfolio risk, financial securities comprise internal specific risk, measured via asset pricing models. Moreover, asset pricing models serve to detain the unsystematic risk of individual assets (Bali et al. 2008, pp. 878-896).

The study contributes to the current discussions on portfolio risk in several ways. To the best of our knowledge, there is no other study that focuses on the diversification benefits provided solely from the largest European stock exchanges. The work provides indications for the financial managers that tend to diversify their portfolio within the largest European stock exchanges. Amid this ongoing debate, the following research questions were formulated: Q1: What is the number of stocks that fully eliminates the diversification risk of European based portfolios? Q2: What are the elements that influence diversification risk the most?

\section{Literature review}

Portfolios are compounded from multiple risk components, such as controlled and uncontrolled risk elements. Individual assets hold their intrinsic risk while grouping them together generates portfolio risk. Building a portfolio that provides a market advantage is an art that depends on the talent of the managers. Diversification is considered a way to spread risk among different asset classes. Globalization, in terms of trade and financial investments, has highlighted the benefits of portfolio diversification. Cross-country investments decrease the average positive correlation within financial assets in the portfolio (Driessen and Laeven 2007; Solnik 1974). Despite the benefits of international diversification, however, financial investors keep an enormous share of their investments domestically (Abid et al. 2014; Van Niuwerburgh and Veldkamp 2009; French and Poterba 1991). Investing in multinational corporations within the country provides risk benefits on an identical scale as investing internationally (Farooqi et al. 2015; Cai and Warnock 2012). A series of studies investigated diversification benefits of investing in the domestic companies that operate on a multinational scale (Berrill et al. 2019; Aliu et al. 2019; Errunza et al. 1999). Driessen and Laeven (2007, pp. 1693-1712) show that the risk benefits from international investments remain, but the benefits accelerate at a decreasing scale. The problem of interconnected economies nowadays has dampened the benefits of international diversification. The Asian banking crisis of 1997 and the financial downturn of 2008 proved that stock markets are highly integrated. Financial problems in one country are easily transmitted to other countries.

Scholars and practitioners are highly interested in the number of stocks that reduce diversification risk. Still, there is no consensus among scholars and practitioners concerning the number of stocks that fully eliminates diversification risk. An earlier study by Evans and Archer (1968, pp. 761-767) shows that a portfolio with 8 to 16 stocks reduces diversification risk. Their work was widely used among finance text- 
books and extensively considered among financial investors. Stevenson and Jennings (1984, p. 236) claim that diversification benefits can be attained in a smaller portfolio than the one proposed by Evans and Archer (1968, pp. 761-767). However, studies have been conducted at diverse time intervals and with different portfolio risk techniques. Gup (1983, p. 185) shows that total diversification benefits are achieved in a portfolio with eight or nine financial securities.

In contrast, the work by Reilly $(1985$, p. 96) indicates that maximum diversification benefits are achieved in a portfolio with 12 to 18 stocks. Elton and Gruber (1977, p. 415-437) confirm that when we move from a portfolio with one to ten stocks, the risk level is reduced by $50 \%$. Increasing the number of stocks within the portfolio from 10 to 20 reduces the risk level by 5\%. However, a portfolio that moves from 20 to 30 stocks reduces the diversification risk by only $2 \%$. Statman (1987, pp. 353-363), in his study, confirm that a well-diversified portfolio must contain a randomly chosen of 30 to 40 stocks. It is the first work that contradicts the results by other scholars that 10 to 15 stocks are enough to reach maximum diversification benefits. Brands and Gallagher (2005, pp. 185-197) examined diversification outcomes on Australian equity funds. Their results show that diversification benefits are achieved when six portfolios are included within one equity fund. However, at the industry level, diversification benefits are achieved with a combination of 47 stocks from two different industries (Aliu et al. 2017, pp. 72-83).

The establishment of the European Union rapidly increased cross-border trading among member states. The introduction of the monetary union further expanded the financial and economic integration within Eurozone countries. Bartram et al. (2007, pp. 1461-1481) investigated the interdependency of seventeen European stock exchanges after the euro currency was established. The results indicate that the common currency raised the dependency of the largest European stock exchanges (Italy, Germany, France, Spain, and the Netherlands) while a recent study by Burzala (2016, pp. 556-571) confirms the co-integration within the DAX, CAC40, and FTSE100. Moreover, stock exchanges tend to be integrated during crisis periods while less integrated in normal times. The European debt crisis of 2011 caused by the Greek government's debt generated an overall downturn on European Stock Exchanges.

Listed companies in the largest European stock exchanges are geographically located within the European continent, but the majority of them operate on a multinational scale. The operational scope exposes them to several transnational risks, such as exchange rate risk, political risk, economic risk, etc. This work does not classify companies into national and multinational; it solely investigates the diversification benefits of investing in European stocks. The results of the study identify portfolio risk outcomes when the number of stocks increases. 


\section{Methodology}

The study used secondary data from the Thomson Reuters Eikon database of the following stock exchanges: FTSE100, CAC40, FTSE MIB, IBEX35, DAX, and MDAX. Stock prices and trading volumes were collected weekly, from January 2007 until December 2017. The stock prices and trading volumes of the listed companies are arranged on identical dates and in an identical currency (euro). Six portfolios with a different number of stocks are constructed, i.e., portfolios with 47, 95, 142, 190, 239, or 287 stocks. Additionally, 32 companies were selected from the CAC40, 30 companies from the FTSE MIB, 35 from the IBEX 35, 30 from the DAX, 60 from the MDAX, and 100 companies from the FTSE 100. The portfolios were constructed from randomly selected stocks. The portfolio of 287 stocks was not randomly chosen since it contains the total number of stocks from the six largest European stock exchanges. The following Markowitz (1952) diversification formula was used to detect the risk level of each portfolio:

$$
\sigma_{k}^{2}=\sum_{i}^{n k} w_{i k}^{2} \sigma_{i k}^{2}+2 \sum_{i}^{n k} \sum_{j<i}^{n k} w_{i k} w_{j k} \sigma_{j k} \rho_{i j k}
$$

where: $\sigma^{2}$ - variance of returns (stock prices of individual listed companies in the stock indexes), $\sigma$ stands for the standard deviation of returns (stock prices of the individual listed companies in the stock index) while $\varphi(i, j)$ shows the correlation coefficient within returns (stock prices of the individual listed companies in the stock index). $\sigma_{k}^{2}$ of the portfolio in year $k$ is computed on the sample of $n_{k}$ companies. The index $i$ indicates a company, $j$ is an auxiliary index assuring that the covariance is computed on distinct companies, $\omega$ represents the weight of each listed company in the stock index within the portfolio based on their trading volume, and $\omega^{2}$ represents the squared weight.

The formula was implemented from the following programs: Python 3.6.3, Numpy (version: 1.13.3), and Jupiter Notebook (version: 5.2.0). The process starts by separating the columns that contain the stock prices and trading volumes of the listed companies in the largest European Stock Exchanges.

The calculation of the weighted average returns (WAR) does not consider dividends declared from the listed companies. WAR is generated solely from the price movements of the individual stocks (capital gains or losses). The following WAR formula was used to calculate the weighted average rate of returns for the portfolio:

$$
w a r=\sum_{i=1}^{n} r_{i} w i_{i}
$$

where: war - weighted average rate of return for the portfolio; $r_{i}$ - weights of stocks within the portfolio; $r_{i}$-stock's required rate of return within the portfolio.

The model is not built on equal weights but on changeable weights. The weights within each portfolio are determined from the trading volume that the listed companies have within their stock exchanges. 


\section{Research results}

The study aims to identify diversification benefits when the number of stocks in the portfolio increases. Portfolio risk is influenced by multiple elements, such as correlation within financial assets, concentration level, and volatility of returns. An increase in the positive correlation within financial securities in the portfolio increases the diversification risk, and vice versa. Diversification risk increases equally when the portfolio concentrates on a few securities. However, volatility is considered a key risk component that indicates the risk level within the group of financial assets.

In this section, we measured the average risk level and weighted average returns linked with the six diverse portfolios for the period 2007-2017. The results are presented in Table 1. Portfolio A is built with 47 stocks, Portfolio B with 95 stocks, while Portfolio $\mathrm{F}$ has 287 stocks. Each portfolio has been simulated with five trials based on an identical number of stocks. The stocks were selected randomly from the six largest European Stock Exchanges (FTSE100, CAC40, FTSE MIB, IBEX35, DAX, and MDAX). The results of the study show that moving from portfolio A to Portfolio $\mathrm{B}$, the risk level is reduced by $28.47 \%$, while from Portfolio B to Portfolio C, the risk level is reduced by $17.34 \%$. However, when moving from Portfolio C to Portfolio D, the risk level is reduced by only $9.87 \%$, while from Portfolio $\mathrm{D}$ to $\mathrm{E}$, the risk falls by $6.84 \%$. The risk level is reduced by only $2.9 \%$ when we move from Portfolio E to Portfolio F. The risk level falls by $51.82 \%$ when we move from Portfolio A (47 stocks) to Portfolio F (287). In order to reduce the diversification risk by $50 \%$, we need to add, on average, 240 randomly selected European stocks. In contrast, moving from a portfolio with 47 stocks to a portfolio with 287 stocks increases the weighted average returns by $3.53 \%$.

Table 1. The results of the average risk level and weighted average returns linked with the six different portfolios

\begin{tabular}{|l|c|c|c|c|c|c|}
\hline \multicolumn{1}{|c|}{ Portfolios } & Years & $\begin{array}{c}\text { Number } \\
\text { of stocks }\end{array}$ & $\begin{array}{c}\text { Average } \\
\text { Volatility }\end{array}$ & $\begin{array}{c}\text { Average } \\
\text { Correlation }\end{array}$ & $\begin{array}{c}\text { Average } \\
\text { risk }\end{array}$ & $\begin{array}{c}\text { Weighted } \\
\text { average } \\
\text { returns }\end{array}$ \\
\hline Portfolio A & $2007-2017$ & 47 & 4.32 & +0.51 & 1.37 & $0.03 \%$ \\
\hline Portfolio B & $2007-2017$ & 95 & 3.51 & +0.39 & 0.98 & $2.20 \%$ \\
\hline Portfolio C & $2007-2017$ & 142 & 3.01 & +0.31 & 0.81 & $2.65 \%$ \\
\hline Portfolio D & $2007-2017$ & 190 & 2.82 & +0.29 & 0.73 & $3.09 \%$ \\
\hline Portfolio E & $2007-2017$ & 239 & 2.67 & +0.27 & 0.68 & $2.86 \%$ \\
\hline Portfolio F & $2007-2017$ & 287 & 2.59 & +0.26 & 0.66 & $3.56 \%$ \\
\hline
\end{tabular}

Source: authors' calculations based on the Thomson Reuters Eikon database.

An additional element of portfolio risk is correlation within stocks. The correlation from Table 1 is the average indicator from the correlation matrix of each portfolio. The average positive correlation declines continuously when the number of stocks in the portfolio is increased. The positive correlation decreases by $23 \%$ when we move from Portfolio A to B, while from Portfolio B to C, the average positive correlation 
declines by $20.5 \%$. However, the average positive correlation decreases by only $3.7 \%$ when we move from Portfolio E to F. Volatility measured by the standard deviation of returns is measured on the average terms. Volatility in Table 1 indicates the average standard deviation of all stocks within the portfolios. The average volatility decreases by $18.75 \%$ when we move from Portfolio A to Portfolio B, while from Portfolio B to C, it decreases by $14.22 \%$. The average volatility declines by only $2.99 \%$ when we move from Portfolio E to F.

Portfolio A was simulated five times with an identical number of randomly selected stocks from the six largest European stock exchanges. The average risk level in Portfolio A (1.37) represents the average risk of five different portfolios with an identical number of stocks. The same process was conducted for each portfolio (B, C, D, E, F).

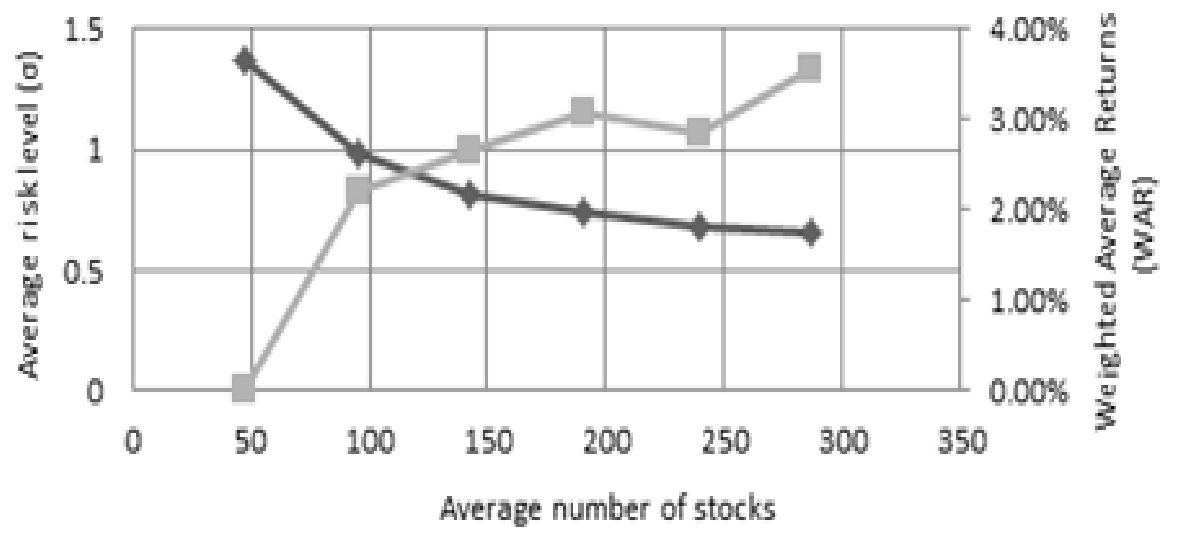

Chart 1. The relationship between the average number of stocks, average risk level, and weighted average returns

Source: authors' calculations based on the Thomson Reuters Eikon database.

Chart 1 represents the relationship between the average number of stocks in the portfolio and the average risk level (black line), and the relationship between the average number of stocks and the weighted average returns (gray line). According to the results presented in Chart 1, the average risk level decreases when the average number of stocks increases. This relationship is in line with the portfolio theories that state that more stocks in a portfolio reduces the risk level. The risk level is constantly reduced when we move from portfolios with 47 stocks to a portfolio with 287 stocks. In contrast, when the risk level decreases, the weighted average returns increase. This contradicts the portfolio theories. Since the portfolios are built with changeable weights, the WAR move in the opposite direction from the average risk level. While stocks in the portfolios hold diverse trade volumes, the study measured the weighted average returns instead of the annual returns.

The phenomenon is explained in average terms, although individual portfolios might not deliver identical outcomes. The portfolios (A, B, C, D, E, and F) show an average risk and return relationship from 2007 to 2017. 


\section{Conclusion}

Financial investors tend to reduce diversification risk via investing in financial securities that are less correlated. International financial investments cannot fully eliminate unsystematic risk since, nowadays, economies tend to be highly interconnected. However, there is an ongoing debate among scholars and practitioners concerning the number of stocks that fully removes risk exposure of the portfolio. This study identifies diversification benefits when the number of stocks in the portfolio increases. Stocks were selected from companies listed on the six largest European stock markets. The portfolios were not exposed to exchange rate risk, except for the randomly selected stocks from the FTSE100.

Portfolio risk is influenced by diversifiable risk (unsystematic risk) and market risk (systematic risk). Unsystematic risk includes elements such as correlation within financial assets, weight concentration, and volatility of returns. Fluctuations of these inputs influence the risk level of the portfolio. The results of the study confirm that the number of stocks is important in reducing the risk level of the portfolio. An increasing number of stocks in the portfolio permanently reduces the risk level of the portfolio. Moving from a portfolio with 47 stocks to a portfolio with 95 stocks reduces the risk level by $28.47 \%$. In order to reduce the risk exposure by $50 \%$, it requires an additional 240 European stocks within the portfolio. Diversification benefits increase on the optimal scale when the portfolio contains more than 139 stocks. The average correlation and average volatility decrease the bigger the size of the portfolio. The average correlation decreases by $23 \%$ when we move from Portfolio A to B, but by only $3.7 \%$ moving from Portfolio E to F. Moving from Portfolio A to B, the average volatility decreases by $18.75 \%$, while from Portfolio E to F, it decreases only by $2.99 \%$. The average correlation decreases on a larger scale and with higher speed than average volatility when the number of stocks increases in the portfolio.

In contrast, an increase in the number of stocks increases the weighted average returns (WAR) of the portfolio. The results of WAR go against the general paradigms in portfolio management. The results of the study show that an increase in the average number of stocks reduces average portfolio risk, which confirms conventional paradigms on the portfolio theory. However, when the average risk level declines, the weighted average returns increase, which goes against the portfolio management theories. Weighted average returns move in the opposite direction from the average risk level, since the portfolios are built with changeable weights. The study measured weighted average returns, not annual returns, because stocks in the portfolio hold diverse trade volumes. Future research could identify if the study outcomes contradict investment theories when portfolios are arranged with identical weights and involving dividends as part of the portfolio returns.

The study does not consider transaction costs imposed on investors when buying and selling stocks. An additional limitation of the study is that portfolios are built only with European stocks, while diversification is also achieved from investing in bonds, 
real estate, and other international financial assets. Weighted average returns are measured only with capital gains or losses but not from dividends as significant revenue for investors.

\section{References}

Abid, F., Leung, P., Mroua, M., Wong, W. (2014), International diversification versus domestic diversification: Mean-variance portfolio optimization and stochastic dominance approaches, "Journal of Risk and Financial Management", Vol. 7 (2). https:// doi.org/10.3390/jrfm7020045

Aliu, F., Krasniki, B., Knapkova, A., Aliu, F. (2019), Interdependence and Risk Comparison of Slovak, Hungarian and Polish Stock Markets: Policy and Managerial Implications, "Acta Oeconomica”, Vol. 69 (2). https://doi.org/10.1556/032.2019.69.2.6

Aliu, F., Pavelkova, D., Dehning, B. (2017), Portfolio risk-return analysis: The case of the automotive industry in the Czech Republic, "Journal of International Studies", Vol. 10 (4). https://doi.org/10.14254/2071-8330.2017/10-4/5

Bali, T., Cakici, N., Levy, H. (2008), A model-independent measure of aggregate idiosyncratic risk, "Journal of Empirical Finance", Vol. 15 (5).

Bartram, S., Taylor, S., Wang, Y. (2007), The Euro and European financial market dependence, "Journal of Banking \& Finance", Vol. 31 (5). https://doi.org/10.1016/j.jba nkfin.2006.07.014

Berrill, J., Kearney, C., O’Hagan-Luff, M. (2019), Measuring the diversification benefits of investing in highly internationalised firms, "International Business Review", Vol. 28 (4). https://doi.org/10.1016/j.ibusrev.2019.01.005

Brands, S., Gallagher, D. (2005), Portfolio selection, diversification and fund-of-funds: a note, "Accounting \& Finance", Vol. 45 (2). https://doi.org/10.1111/j.1467-629x.20 04.00130.x

Burzala, M. (2016), Contagion Effects in Selected European Capital Markets During the Financial Crisis of 2007-2009, "Research in International Business and Finance", Vol. 37 (May). https://doi.org/10.1016/j.ribaf.2016.01.026

Cai, F., Warnock, F. (2012), Foreign exposure through domestic equities, "Finance Research Letters", Vol. 9 (1). https://doi.org/10.1016/j.frl.2011.12.001

Christoffersen, P., Errunza, V., Jacobs, K., Langlois, H. (2012), Is the potential for international diversification disappearing? A dynamic copula approaches, "The Review of Financial Studies", Vol. 25 (12). https://doi.org/10.1093/rfs/hhs104

Damodaran, A. (2012), Damodaran on valuation: security analysis for investment and corporate finance, John Wiley \& Sons, New York. https://doi.org/10.1002/9781119 201786

Driessen, J., Laeven, L. (2007), International portfolio diversification benefits: Cross-country evidence from a local perspective, "Journal of Banking \& Finance", Vol. 31 (6). https://doi.org/10.1016/j.jbankfin.2006.11.006

Elton, E.J., Gruber, M.J. (1977), Risk reduction and portfolio size: An analytical solution, “The Journal of Business”, Vol. 50 (4). https://doi.org/10.1086/295964 
Errunza, V., Hogan, K., Hung, M.W. (1999), Can the gains from international diversification be achieved without trading abroad?, "The Journal of Finance”, Vol. 54 (6). https://doi.org/10.1111/0022-1082.00182

Evans, J.L., Archer, S.H. (1968), Diversification and the reduction of dispersion: an empirical analysis, "The Journal of Finance”, Vol. 23 (5). https://doi.org/10.2307/2325905

Fama, E.F. (1968), Risk return and equilibrium: some clarifying comments, "The Journal of Finance”, Vol. 23 (1). https://doi.org/10.1111/j.1540-6261.1968.tb02996.x

Farooqi, J., Huerta, D., Ngo, T. (2015), Should you globally diversify or let the globally diversified firm do it for you?, "The Quarterly Review of Economics and Finance", Vol. 57. https://doi.org/10.1016/j.qref.2015.02.005

French, K.R., Poterba, J.M. (1991), Investor diversification and international equity markets, National Bureau of Economic Research, Working Paper No. 3609. https://www .nber.org/papers/w3609.pdf (accessed: 23.01.2019).

Gup, B.E. (1983), The Basics of Investing (2nd ed.), Wiley \& Sons, New York.

Kacperczyk, M., Sialm, C., Zheng, L. (2005), On the industry concentration of actively managed equity mutual funds, "The Journal of Finance", Vol. 60 (4). https://doi.org /10.1111/j.1540-6261.2005.00785.x

Kumar, A. (2007), Do the diversification choices of individual investors influence stock returns?, "Journal of Financial Markets", Vol. 10 (4). https://doi.org/10.1016/j.finmar .2007 .06 .003

Lintner, J. (1965), Security prices, risk, and maximal gains from diversification, "The Journal of Finance”, Vol. 20 (4). https://doi.org/10.2307/2977249

Markowitz, H. (1952), Portfolio selection, “The Journal of Finance”, Vol. 7 (1). https:// doi.org/10.2307/2975974

Meucci, A. (2009), Managing diversification, "Risk", Bloomberg Education \& Quantitative Research and Education Paper, http://ssrn.com/abstract=1358533 (accessed: 30.01.2019).

Reilly, F.K. (1985), Investment Analysis and Portfolio Management (2nd ed.), Dryden Press, San Francisco.

Roll, R. (2013), Volatility, correlation, and diversification in a multi-factor world, "Journal of Portfolio Management”, Vol. 39 (2). https://doi.org/10.3905/jpm.2013.39.2.011

Sharpe, W.F. (1964), Capital asset prices: A theory of market equilibrium under conditions of risk, "The Journal of Finance”, Vol. 19 (3). https://doi.org/10.2307/2977928

Skintzi, V.D., Refenes, A.P.N. (2005), Implied correlation index: A new measure of diversification, "Journal of Futures Markets: Futures, Options, and Other Derivative Products”, Vol. 25 (2). https://doi.org/10.1002/fut.20137

Solnik, B.H. (1974), Why not diversify internationally rather than domestically?, "Financial Analysts Journal", Vol. 30. https://doi.org/10.2469/faj.v30.n4.48

Statman, M. (1987), How many stocks make a diversified portfolio?, "Journal of Financial and Quantitative Analysis”, Vol. 22 (3). https://doi.org/10.2307/2330969

Stevenson, R.A., Jennings, E.H. (1984), Fundamentals of Investments (3 ${ }^{\text {rd }}$ ed.), West Publ. Co., San Francisco.

Van Nieuwerburgh, S., Veldkamp, L. (2009), Information immobility and the home bias puzzle, "The Journal of Finance", Vol. 64 (3). https://doi.org/10.1111/j.1540-62 61.2009.01462.x 


\section{Streszczenie}

\section{Modelowanie optymalnego portfela: przypadek największych europejskich giełd papierów wartościowych}

Optymalizacja portfela jest głównym przedmiotem zainteresowania zarządzających portfelem. Dobór papierów wartościowych jest zależny od skłonności inwestora do podejmowania ryzyka. W niniejszym opracowaniu dokonano pomiaru zmian relacji ryzyko-zysk w miarę wzrostu liczby akcji w portfelu. Stworzono sześć różnych portfeli o liczbie akcji wynoszącej odpowiednio: 47, 95, 142, 190, 239 i 287 akcji. Dane dotyczące cen akcji i wolumenu obrotu były zbierane co tydzień z sześciu największych europejskich giełd papierów wartościowych (FTSE100, CAC40, FTSE MIB, IBEX35, DAX i MDAX). Do pomiaru poziomu ryzyka poszczególnych portfeli zastosowano wzór znany z teorii dywersyfikacji Markowitza (1952). Wyniki analizy pokazują, że ryzyko dywersyfikacji maleje dla portfeli o coraz większej ilości akcji (od 47 akcji do 287 akcji w portfelu). Średni ważony zwrot z portfela rośnie dla portfeli o większej liczbie akcji, co jest sprzeczne ze standardowymi teoriami portfela. Wyniki analizy mogą być przydatne dla inwestorów, którzy koncentrują się wyłącznie na największych europejskich giełdach papierów wartościowych.

Słowa kluczowe: dywersyfikacja portfela, giełdy papierów wartościowych, współczynnik korelacji, zmienność 